\title{
Analysis and Improvement Methods of Unsafe Posture Associated with Various Agricultural Works
}

\author{
Hwa Shik Jung \\ Department of Occupational Therapy, Dongshin University, Naju, 520-714
}

\begin{abstract}
Objective: This paper presents the results of a literature review undertaken to analyze the types and risk factors of unsafe posture in accordance with the crops and the working position and to introduce various ergonomic intervention approaches. Background: There is clear and consistent evidence that agricultural work has been rated as one of the dangerous occupations in the world. A considerable number of adverse health conditions, including musculoskeletal disorders(MSDs) are related to agricultural work. Method: An agricultural work requires squatting, kneeling, and bending(stooping) postures for significant periods of the work day which due to a wide variety of activities such as planting, cultivating and harvesting various agricultural products. Thus, each of these postures is analyzed in detail to recommend the improvement methods. Results: Various unsafe postures in agricultural works are revealed and analyzed. It is proven that ergonomics intervention has the potential benefits to reduce MSDs among agricultural workers. Two types of ergonomic intervention methods were discussed to improve unsafe working postures, engineering controls and administrative controls. Conclusion \& Application: As a concluding remark, this article can be used as a reference manual for the agricultural workers and also used to raise the research community's awareness to the risk of unsafe working postures for workers in agriculture.
\end{abstract}

Keywords: Posture, Squatting, Stooping, Musculoskeletal disorders, Agriculture, Ergonomics

\section{Introduction}

수작업 (manual processing)이란 기계를 사용할 수 없거 나 자동화 시스템을 적용할 수 없는 상황에서 불가피하게 이루어지는 여러 가지 활동으로 구성되며 이는 산업현장에 서 물체를 가공하거나 조립하는 것뿐만 아니라 농어촌과 가정에서 작업을 수행하는데 있어 사람의 힘을 사용하는 작업 등이 포함된다. $\operatorname{NIOSH}(1981 ; 1997)$ 와 Sanders and McCormick(1992)은 이러한 수작업이 사고와 상해를 일 으키는 주된 위험요인이 된다고 보고하고 있으며 이러한 수 작업에서 발생되는 다양한 요인들이 작업자에게 생체역학 적, 생리학적, 심리물리학적인 스트레스를 초래하게 되는데 이중에서도 불안전한 작업자세가 가장 큰 원인이라고 보고
하고 있다.

불안전한 작업자세와 관련된 위험요인을 고찰해보면 목과 어깨 부위와 관련되어 목의 굴곡과 신전, 어깨의 외전, 팔꿈 치가 들리는 자세; 손목과 손 부위와 관련되어 손목의 편 향(radial and ulnar deviation), 손과 앞팔의 회내 및 회외 (pronation and supination), 손바닥 굴곡과 배굴(palmar flexion and dorsiflexion) 등의 자세; 몸통 부위와 관련되 어 몸통굴곡과 신전, 몸통 측면굴곡, 몸통회전 등의 자세; 그리고 하지와 관련되어 쪼그려 앉는 자세와 무릎 꼻는 자세 등이 주요 위험요인으로 분석된다(NIOSH, 1997).

일반적으로 농작업은 작업부하가 많은 철강산업이나 조 선업 등의 과중한 작업들과 비교하여 볼 때 작업부하량에 있어서 큰 차이가 없는 것으로 알려져 있다(Meyers et al., 1997). 특히 농작업자의 근골격계질환(MSDs)은 고질적인 
문제점의 하나로 부각되고 있으며 몸의 과다한 비틀림, 굽 힘, 과다한 반복 등의 농작업 특성은 근골격계질환의 발생 가능성을 크게 높이는 것으로 알려져 있다(Pinzke, 1994). 이러한 위험요인들에 따라 농작업자들에 발생하는 주요증 상은 요통, 건염(tendonitis), 수근관증후군 (carpal tunnel syndrome), 관절염 등으로 보고되고 있다(Hansson, 1990; Hildebrandt, 1995; Nemeth et al., 1990; Putz-Anderson, 1988).

본 연구의 목적은 농작업에 있어서의 불안전한 작업자세 를 인식하고 개선하는데 활용할 수 있는 매뉴얼로서의 역할 을 기대하며 수행되었다. 이를 위하여 다양한 작목과 이들 작목의 생육과정에서 발생하는 불안전한 작업자세에 대해 인간공학적 위험성과 작업자세 개선 대책에 관한 국내외 여 러 연구결과들을 종합하고 정리하였다. 향후 이를 효과적으 로 활용한다면 노동강도를 경감시킴과 동시에 작업능률 향 상과 근골격계질환을 감소시켜 작업자의 건강을 증진시킬 수 있다고 판단한다.

\section{Problems with Unsafe Agricultural Posture}

'06 '08 농촌진흥청의 농부증 발생현황 조사자료(Korean Rural Development Administration, 2011)에 따르면 우 리나라 농업인의 농부증 발생률은 2006년 37.0\%, 2007년 $40.1 \%, 2008$ 년 40.5\%로 지속적으로 상승하고 있다. 최근 농업 기술의 발달로 농작물의 생산효율성은 증대 되었지만 농업인구의 감소와 고령화, 여성화로 인해 인력수급이 어렵 고, 열악한 작업조건과 과도한 반복작업으로 인해 근골격계 질환 발생률이 늘어나고 있다. 이중 근골격계질환은 작목별 로 차이를 보이고 있으나 유병률은 2007년 75.2\%로서 전 체 유병률에 있어서 농림어업인이 비농림어업인에 비해 근 골격계질환이 2 배 이상 높은 것으로 보고되고 있다(Korean Rural Development Administration, 2006; 2007). 또한 2009년 노동부 발표 업종별 산업재해현황분석 재해 발생률 에 따르면 전체산업 재해율은 $0.71 \%$, 이중 농업부문 재해율 은 $1.46 \%$ 로 농업재해가 일반 산업재해보다 약 2.05 배 높은 재해 발생 수준을 보여준다(Ministry of Labor, 2009).

이러한 현황은 외국의 경우도 예외가 아니어서 미국의 경 우 농업인의 직업성 사고 및 질병 중 전체의 $40 \%$ 이상이 근골격계질환과 관련 있다고 보고되고 있으며 이에 따른 비 용 손실도 해결해야 할 가장 중요한 문제로 간주되고 있다 (Brackbill et al., 1994; Gomez et al., 2003; Meyers, 2001; Meyer et al., 1997; Walker-Bone and Palmer, 2002;
Xing et al., 1999).

이와 같이 농업인은 타 산업분야에 비해 근골격계질환 유 발 위험성이 높으며 주로 엉덩이, 무릎, 어깨 및 허리 부위 의 상해 위험이 높은 것으로 알려져 있다(Rural Research Development Institute, 2004: Xing et al., 1999). 특히 타 근로자들에 비해 상대적으로 다리 부위의 유병율이 높으며 실제 농업조사자들을 대상으로 농촌지역 근골격계질환 증상 경험률을 조사한 결과, 남녀의 수치 차이는 있으나 대체로 허리와 다리, 무릎 통증을 호소한다고 하였다(Oh et al., 2001).

작목별 근골격계질환 유병률은 과수농가가 $66.7 \%$ 에 달했 으며, 고추 $60.1 \%$, 축산 $35.3 \%$ 등이다. 근골격계질환의 종 류도 관절염이 $19.1 \%$, 근막통 증후군이 $9 \%$, 추간판탈출증 $8.4 \%$, 만성요통 $6.7 \%$ 등이다(Korean Rural Development Administration, 2007). 이처럼 농업인의 직업성 질환 발생 이 늘고 있는 것은 농업 노동의 특성상 장기간 과도한 노동 과 스트레스 등이 원인이다. 또 부적합한 작업자세, 반복적 인 동작, 과도한 힘 사용, 진동 등은 근골격계질환의 주요 유 발요인이다.

이들 근골격계질환이 모두 불안전한 작업자세로 인한 요 인으로 발생한 것이라고 보기에는 무리가 따르지만 국내 농 업인을 대상으로 실시된 근골격계질환에 대한 증상조사 및 건강진단 결과, 근골격계질환 호소율에서 고추재배 농업인 이 다른 작목에 비해 높게 나타났으며, 특히 허리, 어깨, 무를 등이 주로 문제되는 것으로 나타났다(Korean Rural Development Administration, 2007). 허리를 숙인 자세와 쪼그린 자세가 요구되는 키가 낮은 작물재배의 경우 농작업 자의 허리 및 하지 부위에 근골격계 작업부담이 높은 것으 로 나타났다(Bae et al., 2011; Fathallah et al., 2008; Jin, et al., 2009). 포도재배의 경우 대부분의 작업이 장시간 선 자세로 머리 위로 손을 뻗어 작업이 이루어지는 경우가 많고, 포도 순치기나 알 솎기 작업의 경우에도 장시간 동안 반복 적인 작업을 수행하기 때문에 목, 허리, 어깨, 손, 손목 등에 근골격계질환의 발병률이 높다고 하였다(Kim et al., 2009; Choi et al., 2002; 1997). 특히 트랙터 운전 작업자의 경우 그렇지 않은 작업자들에 비해 약 $10 \%$ 이상 요통의 자각증 상 호소율이 높다고 하였고 이러한 증상들은 전신진동과 자 주 목과 허리를 좌우로 회전하는 운전자세 그리고 장시간 동 안 운전석에 앉아 있는 요인과 관련이 있다고 하였다. 이들 대표적인 농작업자세로 인해 작업자가 받는 건강상의 부정 적인 효과에 대한 연구는 Hildebrandt(1995), Keyserling, et al. (1992), Lee et al. (2007; 2010) 등에서 참조할 수 있다.

Baek and Lee(2008)에 따르면 우리나라 농업인의 농업 특성상 쪼그리고 앉거나 구부린 상태에서 반복작인 작업을 
수행하는 경우가 많기 때문에 장시간 농업에 종사한 경우 동 일 연령대의 도시 여성보다 먼저 노인형 체형으로 변화가 나 타나고 비만이나 관절 부위의 변형 등과 같은 체형변화가 일어나기 쉽다고 하였으며 농업인에 있어서 근골격계질환이 전체 상해 발생율이나 비용면에 있어 가장 중요한 문제라고 지적하였다.

\section{Ergonomic Analysis of Unsafe Agricultural Posture}

일반적으로 농업은 논벼, 과수, 축산, 노지재배, 시설재배 등 5 개 영농유형으로 구분된다. 이러한 영농유형 중 축산을 제외한 나머지 영농유형에서 발생하는 농작업은 농작물이 주체가 되고 작목의 유형에 따라 그리고 작목의 생육과정에 따라 작업내용이 변화한다. 농작업에서 요구되는 작업자세는 대상 농작물의 작업조건(재배작물의 높이나 작업내용) 즉, 현재 작업 대상물의 위치에 따라 결정되는데 이때 선 자세 (standing posture)의 경우 팔꿈치높이 이상, 허리를 구부 려 작업하는 자세(stooping posture)는 무릎높이에서 팔꿈 치높이 사이, 쪼그려 앉는 자세(squatting posture)는 무릎 높이 이하에서 작업하는 경우에 발생한다.

노지나 시설재배 농작물의 높이는 주로 허리높이 이하여 서 정상적으로 서서 작업을 할 수 없기 때문에 허리를 구부 리거나 쪼그려 앉아서 작업하게 된다. 이중 비교적 키가 작 은 농산물의 농사나 밭일작업 등은 주로 쪼그린 상태로 작 업을 수행하게 된다. 포도, 사과, 배와 같은 과수재배 작업은 논벼나 노지재배 작업에 비해 작업위치가 높아 고개와 팔을 장시간 위로 향한 자세가 발생한다.

이와 같은 작업자세는 작목에 따라 항상 똑같은 작업자세 가 계속되는 것이 아니고 파종(육모), 이식(정식), 김매기, 순치기, 가지치기, 유인작업, 과실 매달기, 수정, 수확 등으로 이어지는 농작물의 생육과정에 따라 달라진다. 즉, 작목별뿐 만 아니라 재배단계별로 요구되는 작업자세도 달라진다. 또 한 같은 작목이라도 재배환경과 재배방법이 달라지면 이에 따른 작업자세도 변할 수 있다.

농작업은 이와 같은 부자연스러운 작업자세로 오랜 시간 작업하는 경우가 많기 때문에 뼈와 근육에 대한 부담이 가장 문제가 된다. 즉 목과 어깨, 무릎과 허리의 피로 및 통증이 격심해져서 근골격계질환을 유발하는 경우가 빈번하며, 작업 능률을 떨어뜨린다. 이와 같은 사실은 이미 많은 연구결과들 이 이를 입증하고 있다(Buckle et al., 1986; Chung et al., 2003; Corlett et al., 1986; Grandjean and Hunting, 1977; Li and Buckle, 1999; Pinzke, 1994).
최근 농업의 발전과 더불어 1980년 초부터 농업에 도입 된 온실재배로 인하여 우리나라의 농업은 계절이 없는 농업 으로 바뀌었다. 과채류는 물론이고 화훼, 버섯, 과수에 이르 기까지 모든 작물의 재배에 있어서 온실은 이제 필수적인 시설이 되었다. 이러한 온실은 좁은 공간에서 반복적으로 쪼 그려 앉거나 허리를 구부리고 일하기 때문에 노지재배에 비 해 무릎이나 허리의 통증을 비롯한 여러 부위의 관절통을 많이 유발하게 된다. 한편 과수작업의 경우에는 반복작업이 많고 대부분의 작업위치가 머리 위에 위치하기 때문에 항상 팔 전체를 머리 위로 들어 올림과 동시에 목과 허리를 뒤로 젖힌 상태에서 작업하는 정적인 작업자세로 작업함으로써 목과 허리 부위의 근골격계질환을 발생시킬 가능성이 높다.

Table 1은 작목높이에 따른 작목분류와 작목별 작업자세 및 위험요인에 대해 설명하고 있다.

\section{Improvement Methods for Unsafe Agricultural Posture}

불안전한 작업자세를 야기하는 열악한 작업환경으로부터 농업인의 건강을 보호하고

최대한의 작업능률을 올리기 위해서는 작업자세 개선도구 나 장비 등의 농작업 안전 기술을 적극적으로 이용하는 것이 필수적이다. 이를 위해서 인간공학적 접근법은 농작업에 있 어서 위험요인들을 최소화하는데 많은 도움이 된다고 한다 (Meyers et al., 1995; 1997; 1998; 2000).

\subsection{Engineering control approaches}

농작업에 있어서 발생하는 불안전한 작업자세에 대한 문 제점들을 원천적으로 해결할 수는 없어도 이를 개선하기 위 하여 농업현장에서 좀 더 편안한 상태에서 작업을 할 수 있 게 함으로써 안전성을 향상시키고 육체적 스트레스를 감소 시키도록 작업자세 개선도구를 적극적으로 활용해야 한다. 따라서 농작업자를 위한 작업자세 개선을 위한 작업자세 개 선도구의 활용목적은 농업에 종사하는 작업자들에게 부과되 는 육체적 에너지를 최소화하여 작업자의 작업안전 향상과 건강을 증진시키고 작업을 쉽고 빠르게 수행하게 하여 생산 성을 높이는데 있다.

\subsubsection{Methods for low working position}

바닥에 앉아 작업하는 자세는 가능한 한 작업대를 사용하 여 의자에 앉거나 서서 일하는 작업으로 전환하는 것이 바람 직하며 작업대의 높이는 앉은 자세에서 팔꿈치높이가 적절 
Table 1. The working posture with risk factors according to the height of crops and working positions

\begin{tabular}{|c|c|c|}
\hline 작목높이 & 해당작목 & 작업자세 및 위험요인 \\
\hline 낮은작목 & $\begin{array}{l}\text { - 뿌리작물 } \\
\text { (무, 감자, 고구마, 양파, } \\
\text { 마늘, 당근, 땅콩) } \\
\text { - 잎줄기채소류 } \\
\text { (배추, 상추, 쑥갓, 파) } \\
\text { - 열매채소류 } \\
\text { (수박, 참외, 딸기, 달래) }\end{array}$ & $\begin{array}{l}\text { - 모종파종(육묘)이나 이식(정식), 김매기, 수확작업 등 주로 지면에서부터 } 20 \mathrm{~cm} \text { 이하에서 행 } \\
\text { 해지는 바닥작업 } \\
\text { - 주로 요구되는 작업자세는 쪼그려 앉은 자세이거나 한쪽 무릎을 바닥에 꼻은 자세 또는 두 } \\
\text { 무릎을 껋은 자세 } \\
\text { - 이식(정식) 작업시 팔꿈치와 손목의 굴곡과 신전, 손가락으로 흙 누르기 등의 반복적인 작업 } \\
\text { 으로 인한 손목과 손가락 관절에 부담을 줌 } \\
\text { - 쪼그려 앉는 자세는 무릎관절에 가장 큰 부담을 주며 특히 장시간 정적인 상태로 지속되는 } \\
\text { 경우 관절염과 같은 근골격계질환 발생의 위험을 높이며 이와 더불어 요통과 위의 압박으로 } \\
\text { 인한 위장장해를 일으킬 수 있음 } \\
\text { - 참외의 경우 근골격계질환 증상 유병율은 허리( } 66.2 \%), \text { 다리/무릎 }(50.0 \%), \text { 어깨(48.5\%) 순으로 } \\
\text { 높게 나타남 }\end{array}$ \\
\hline $\begin{array}{l}\text { 낮은- } \\
\text { 중간작목 }\end{array}$ & $\begin{array}{l}\text { • 수도작물 } \\
\text { • 미나리 }\end{array}$ & $\begin{array}{l}\text { - 벼는 모판에 파종하여 육묘한 후 본답에 이앙할 때 농기계의 접근이 어려운 곳의 직접 모심 } \\
\text { 기 및 잡초제거 작업으로 구성됨 } \\
\text { - 벼나 미나리의 작업은 주로 지면에서 이루어지나 물을 가두어 재배하는 작물 특성상 쪼그 } \\
\text { 려 앉을 수가 없기 때문에 허리를 굽히고 목의 굴곡과 신전을 반복하여야만 작업할 수 있 } \\
\text { 으므로 목과 척추관절에 가장 큰 부담을 줌 }\end{array}$ \\
\hline 중간작목 & $\begin{array}{l}\text { - 고추 } \\
\text { - 가지 }\end{array}$ & $\begin{array}{l}\text { - 모종이식(정식)과 김매기 등은 주로 지면에서 이루어지며 목, 허리, 어깨의 굴곡과 팔꿈치와 } \\
\text { 손목의 굴곡과 신전, 손가락으로 흙 누르기 등의 작업으로 구성되며 주로 고랑에 쪼그려 } \\
\text { 앉아서 수행되기 때문에 무릎관절의 부담이 큼 } \\
\text {-순지르기, 수확작업, 지지대 묶기 등은 작업위치가 높아지므로 허리와 목을 숙인 자세가 요 } \\
\text { 구되어 목과 허리, 손과 손목의 굴곡/신전에 대한 부담이 큼 } \\
\text { - 작업위치가 생육단계에 따라 변하므로 몸 전체(무릎, 척추관절, 목)에 부담을 줌 }\end{array}$ \\
\hline $\begin{array}{c}\text { 중간- } \\
\text { 높은작목 }\end{array}$ & $\begin{array}{l}\text { - 오이 } \\
\text { - 호박 } \\
\text { - 토마토 } \\
\text { - 멜론 } \\
\text { - 감귤, 한라봉 }\end{array}$ & $\begin{array}{l}\text { - 오이, 호박, 토마토, 멜론 등은 대표적인 넝쿨식물들로서 주요작업은 육묘, 정식, 순지르기, } \\
\text { 가지치기, 유인줄 매기, 과실 매달기, 수정, 수확작업 등이 있으며 감귤과 한라봉은 넝쿨식 } \\
\text { 물은 아니나 요구되는 작업은 유사함 } \\
\text { - 육묘 및 정식작업은 목, 허리, 어깨의 굴곡과 팔꿈치와 손목의 굴곡과 신전, 손가락으로 흙ㄱ } \\
\text { 누르기 등이 쪼그려 앉은 상태에서 계속 반복됨 } \\
\text { - 정식작업 후 육묘가 자라면서부터 순지르기, 가지치기, 유인작업 등에는 허리높이 이상에서 } \\
\text { 목 굴곡/신전, 허리 굴곡/신전 등의 부적절한 자세가 요구됨 } \\
\text { - 수정 및 수확에는 작업높이가 일정치 않고 넝쿨에 의하여 대상물이 가려지는 가림 현상으로 } \\
\text { 인해 쪼그려 앉기, 허리의 구부림, 어깨 굴곡/신전, 팔꿈치 굴곡/신전, 손목의 굴곡/신전 등의 } \\
\text { 자세 등으로 인한 손목과 상지, 허리, 무릎 등 몸 전체에 부담을 줌 } \\
\text { - 전지가위를 사용하는 수확작업은 손과 손목에 반복적인 접촉스트레스로 인한 과도한 압박과 } \\
\text { 파악으로 인하여 손목의 편향이 발생하여 수근관증후근(Carpal Tunnel Syndrome)을 일으키는 } \\
\text { 손 부위의 주요 근골격계질환 위험 요인임 }\end{array}$ \\
\hline 높은작목 & $\begin{array}{l}\text { - 과수작목 } \\
\text { - 포도 } \\
\text { - 참다래 } \\
\text { - 배 } \\
\text { - 단감 } \\
\text { - 사과 } \\
\text { - 석류 } \\
\text { - 매실 } \\
\text { - 뽕 }\end{array}$ & $\begin{array}{l}\text { - 주요작업은 선 자세(standing posture)에서 순지르기, 가지 유인작업, 가지치기, 적과, 수정, 봉 } \\
\text { 지 씌우기, 수확작업 등으로 이루어짐 } \\
\text { - 과수작업의 경우 대부분의 작업위치가 어깨나 머리 위에 위치하기 때문에 대부분 팔을 어 } \\
\text { 깨 위로 들어 올린 상태에서 목과 허리를 뒤로 젖혀서 작업하는 정적인 작업자세가 문제됨 } \\
\text { - 이에 따라 경부와 상지의 근골격계 증후군이 발생하며 주로 반복적인 과도한 신전과 굴곡 } \\
\text { 작용에 영향을 받으며 높게 위치한 과일을 수확하기 위해 고개를 과도하게 신전하는 경우 } \\
\text { 가 이에 해당함 } \\
\text { - 전지가위를 사용하는 과수 수확작업은 손과 손목에 반복적인 접촉스트레스로 인한 과도한 } \\
\text { 압박과 파악으로 인하여 수근관증후근을 일으킬 수 있음 } \\
\text { - 오랫동안 선 자세의 작업은 하지의 혈액이 심장으로 순환하는 것을 어렵게 하므로 다리에 } \\
\text { 상당한 부담을 주어 피로가 쉽게 발생함 } \\
\text { - 또한 위를 쳐다보는 작업은 눈과 눈꺼풀, 팔, 어깨, 목, 허리에 피로를 가중시킴 }\end{array}$ \\
\hline
\end{tabular}


하다. 이때 의자의 경우 높낮이가 조절될 수 있는 것을 사용 하면 더욱 효과적이다. 서서 작업하는 작업대의 높이는 작업 특성에 따라 정밀도가 높은 작업의 경우 팔꿈치 보다 위에 위치하도록 하며, 손을 자유롭게 움직여야 하는 작업은 팔꿈 치 보다 조금 낮게, 무거운 물건을 다루는 작업인 경우 팔꿈 치 보다 20 30cm 낮게 위치하도록 한다. 즉 작업의 내용 과 자신의 신체 크기에 맞는 적정높이에 따라 작업대의 높 이를 조절할 수 있으면 좋으나 여의치 않을 때에는 자기의 팔꿈치높이 보다 약간 높게 제작하여 상황에 따라 발판을 사용하여 높이를 조절하도록 한다(Jung and Jung, 2005; 2007 ; 2008). 이와 같은 작업대는 포장대, 선별대, 화훼 결 속대 등 다용도로 활용할 수 있으며 이를 통하여 무릎, 엉덩 이, 허리 통증 완화와 작업량 또한 증가시킬 수 있다.

각종 농산물 파종, 수확, 선별, 제초작업 등에 요구되는 쪼그린 작업자세에서 오는 피로를 경감시키고 작업능률 향 상을 위하여 농작업용 방석(쿠션), 깔판이나 의자 등을 활용 할 수 있다. 특히 이동이 많은 작업의 경우 무릎 보호대를 착용함으로써 무릎 및 허리 통증을 예방할 수 있다. 또한 엎 드려 작업할 수 있는 기기를 개발 활용함으로써 쪼그리거나 엎드려 작업하는 자세를 개선할 수도 있다.

\subsubsection{Methods for middle working position}

엉덩이에 착용하여 사용이 가능하며 신장이나 작업에 맞 추어 높낮이 조절이 가능한 작업용 보조의자를 사용하면 허 리를 굽히는 자세를 감소시킬 수 있다. 또한 허리보조 및 요 통예방 벨트 등을 이용하면 허리 통증을 감소시킬 수 있다.

\subsubsection{Methods for high working position}

서서 오랜 시간 어깨위로 팔을 뻗고 고개를 들어 작업하는 자세는 가능한 한 의자에 앉거나 기대서 일하는 작업으로 전 환하며 보조도구를 이용하도록 한다. 원예작업의 경우 넓은 상판의 이동식 사다리를 활용하여 적과, 봉지 싸기, 과일수 확, 전지작업 등 사계절 작업대를 활용한다. 즉 현재 사용하 고 있는 사다리의 발 받침대 폭을 넓히고 수직적 개념으로 설계된 것을 수직적 개념과 수평적 개념이 결합된 사다리로 설계 - 활용하는 것이 바람직하다. 또한 계단식 이동작업대를 사용하면 고소 작업이 가능하다.

작물높이가 높아서 작업자가 팔을 들고 작업하는 경우가 많은 포도, 사과, 배 등의 유실수 작업에서는 목과 어깨의 피 로를 경감시키는 보조도구의 개발 및 활용이 요구된다(Choi et al., 1999). 따라서 목 보조기 착용은 목과 어깨를 들어 올려 작업할 때 작업자의 목에 가해지는 힘을 분산시켜 이 상적인 생체역학적 자세를 제공(안정된 어깨뼈 움직임 유도 는 목의 피로를 최소화)함으로써 목과 어깨 부위의 근골격 계질환을 예방할 수 있다.

\subsubsection{Methods for working with hands}

과수작업 중 행해지는 전지작업과 수확작업에 사용되는 전지가위는 손과 손목에 반복적인 접촉스트레스로 인한 과 도한 압박과 파악뿐만 아니라 손목의 편향이 발생하여 수근 관증후근(Carpal Tunnel Syndrome)을 일으키는 손 부위의 주요 근골격계질환 위험요소이다.

이러한 손과 팔과 관련된 불안전한 작업자세 교정 및 예 방을 위하여 인간공학적 설계도구 사용을 통한 농작업 안전 을 향상시킬 수 있다. 즉 손목이 중립위치가 아닌 상태에서 사용하도록 제작된 공구로 장시간 작업을 하면 손목에서 손 과 손가락으로 연결된 신경과 힘줄에 스트레스를 증가시켜 손목터널 증후군이 발생되기 쉬우나 인간공학적으로 설계된 수공구를 사용하게 되면 사용시 손목과 팔을 같은 평면에 위 치하게 함으로써 오래 사용하여도 손목이 아프지 않는다.

\subsubsection{Methods for converting working environment}

이랑이나 고랑에 대한 작업자중심 작업환경 개선을 통하 여 작업자세를 개선할 수 있다. 이랑의 경우 두둑 폭을 성인 의 수평면 최대 작업력(손이 닿는 최대범위) 이내로 설정하 고 두둑의 높이는 되도록 높게 하여 허리를 굽히거나 쪼그리 는 자세를 개선할 수 있다. 고랑의 경우도 성인 남자의 어깨 너비를 확보하고, 바닥은 농기구 사용이 편하도록 평평하게 한다. 수경재배와 같이 작물의 재배높이를 허리높이나 팔꿈 치높이로 올리는 재배방식도 이에 해당한다.

\subsection{Administrative control approaches}

최근 들어 산업현장뿐만 아니라 농어촌에도 자동화가 가 속화 되면서 작업자의 안전성과 편리성을 높이기 위한 다양 한 방안이 제시되고 있다. 특히 농작업에 있어서 작업자의 작업부하를 절감시키기 위한 유용한 장치 및 도구 개발에 많 은 연구들이 이루어지고 있다. 하지만 여전히 농업현장에서 대부분의 작업들이 불안전한 자세로 수행할 수밖에 없는 경 우가 자주 발생한다. 따라서 앞서 제시된 여러 가지 농작업 보조도구의 적극적인 활용과 함께 작업자세 개선이 어려운 상황이나 환경에서는 다음과 같이 관리적인 개선방법을 병 행함으로써 잘못된 작업자세로 인해 향후 발생 가능한 근골 격계질환을 예방할 수 있으며 이미 발생한 경우라도 악화되 지 않도록 다음과 같은 작업관리 방법을 습관화 한다.

- 같은 작업자세를 장시간 유지한 후에는 단순한 휴식보다 근육의 경직과 혈액순환을 돕는 가벼운 체조나 관절 스트 레칭 실시

- 작업도중 작업하는 자세와 항상 반대의 동작을 실시함으 로써 관절의 피로감소와 유연성을 제공한다. 예를 들어 목 
이나 허리를 굽힌 작업 이후 목과 허리를 뒤로 펴서 스트 레칭 실시

- 같은 작업을 지속적으로 하지 말고 가능하면 다른 작업과 교대로 수행하여 변화 있게 일을 한다. 낮은(높은) 위치의 작업 이후 높은(낮은) 위치의 작업으로 전환

- 특히 서서 하는 작업은 한발을 교대로 번갈아 가면서 체 중이 실리는 발을 앞뒤로 전환

- 불안전한 농작업자세 개선을 위한 노력의 일환으로 작업 자세 개선에 필요한 보조도구 사용에 대한 현장 교육과 재배 작목별, 생육과정별 올바른 작업자세에 대한 지도

\section{Discussion and Conclusion}

일반적으로 작업자세 개선도구는 불합리한 작업자세를 개 선하여 노동강도를 경감시켜 작업능률 향상과 근로자의 건 강을 증진시키기 위한 목적으로 활용되고 있다. 최근 농촌에 서 실용화되고 있는 농작업 보조도구는 각종 농산물 수확운 반차에서부터 이동식 작업의자 등이 농작업자의 불안전한 작업자세를 개선하기 위하여 사용되고 있다. 그러나 불안전 한 작업자세를 개선할 수 있는 각종 도구에 대한 개발의 여 지는 여전히 많은 실정이다.

불안전한 작업자세를 유발하는 작업위치나 이에 따른 적 절한 작업자세 개선도구가 작업자에게 제공되지 않으면 작 업자들은 작업자체에서 파생되는 부담뿐만 아니라 이로 인 한 불편이 가중되어 높은 작업부하를 유발하게 된다. 따라서 작업위치나 작업자세 개선도구를 작업자의 신체치수나 작업 내용에 적절하도록 제공한다면 작업부하를 최소화 할 수 있 다. 이에 따라 인간공학적 설계요건을 고려하여 작업자에 적 합한 농작업 환경을 제공할 수 있지만 이에 따른 엄청난 비 용을 감수하여야 한다. 특히 작업 대상물이 바닥에 고정되어 있는 농작물을 재배하는 경우 작업위치를 작업자에게 편리 하도록 변경하기가 쉽지 않다. 더욱이 농촌에서 행해지는 작 업의 경우 대부분 비정형화된 작업이기 때문에 이러한 개선 대책에 대한 고려조차도 어렵게 된다. 그러므로 작업위치에 따라 적절한 작업자세 개선도구와 농작업관리 관리방법을 제공한다면 비용을 절감하는 동시에 작업부하를 최소화 할 수 있는 최적의 대안이 될 수 있다.

본 연구는 농작업에 있어서 불안전한 작업자세에 대한 국 내 · 외 문헌조사 및 농작업 위험요인조사를 통해서 농작업 시 근골격계질환의 위험성을 파악하였고 불안전한 작업자세 를 개선하는데 활용될 수 있는 작업자세 개선도구에 대해서 도 소개하였다. 본 연구에서 제안된 작업자세 개선도구들의 도입은 어느 개인기업 차원에서 개발 - 보급하기보다는 국민
의 건강과 안전을 도모하기 위한 거시적인 목표를 가지고 국가 정책적인 차원에서 추진하려는 노력도 필요하다고 사 료된다.

장래에 요구되는 관련연구 내용 및 방향에 대해 살펴보면, 사회적 비용 손실 감소와 농업인의 효율성 제고 및 농업인의 근골격계질환 예방과 재활치료를 위해, 불안전한 작업자세로 인한 농작업 종사자들의 근골격계질환 유병률 실태 조사에 대한 연구가 추후 예방, 조기진단, 치료, 재활 등의 연구과제 에 우선되어야 할 것으로 판단한다.

\section{Acknowledgements}

This research was supported by the Dongshin University research grants.

\section{References}

Choi, J. W., et al. Effects of using convenient tool (put-on-style-stool) on farm worker's physiological responses, Korean Journal of Rural Living Science, 8(1), 1-5, 1997.

Choi, J. W., et al. Study on farm work environment and physical load in korea-focused on farm work model by crops-, Korean Journal of Rural Living Science, 10(2), 85-100, 1999.

Choi, J. W., et al. Evaluation of farmer's workload and thermal environments during harvesting grape in summer, Journal of the Korean Home Economics Association, 40(11), 193-205, 2002.

Bae, K. J., et al. The prevalence of musculoskeletal symptoms and the ergonomic risk factors among oriental melon-growing farmers, Korean Journal of Occupational Environmental Medicine, 23(1) 1225-3618, 2011.

Baek, Y. J. and Lee, K. S., Characteristics of the body shape of korean woman farmers by crops, The Journal of the Korean Society of Clothing and Textile, 32(10), 1584-1594, 2008.

Brackbill R. M. and Cameron, L. L., Behrens, V., Prevalence of chronic diseases and impairments among US farmers, 1986-1990. American Journal of Epidemiology, 139(11), 1055-1065, 1994.

Buckle, P. W., Stubbs, D. A. and Baty, D., Musculo-skeletal Disorders (and discomfort) and Associated Work Factors. In: Corlett, E. N., Wilson, J., Manenica, I. (Eds.), The Ergonomics of Working Postures: Models, Methods and Cases, Taylor \& Francis, London, 19-30, 1986.

Chung, M. K., Lee, I. and Kee, D., Effect of stool height and holding time on postural load of squatting postures, International Journal of Industrial Ergonomics, 32(5), 309-317, 2003.

Corlett, E. N., Wilson, J. and Manenica, I., The Ergonomics of Working 
Postures: Models, Methods and Cases, Taylor \& Francis, London, 1986.

Fathallah, F. A. Miller, B. J. and Miles, J. A., Low back disorders in agriculture and the role of stooped work: scope, potential interventions, and research needs, Journal of Agricultural Safety and Health, 14(2), $221-245,2008$

Gomez, M. I., Hwang, S., Stark, A. D., May, J. J., Hallman, E. M. and Pantea, C. I., An analysis of self-reported joint pain ergonomic intervention for preventing musculoskeletal disorders 69 among New York farmers. Journal of Agricultural Safety and Health, 9(2): 143 $-157,2003$.

Grandjean, E. and Hunting, W., Ergonomics of postures review of various problems of standing and sitting postures, Applied Ergonomics, 8(3), 135-140, 1977.

Hansson. J. E., Ergonomics design of large forestry machines, International Journal of Industrial Ergonomics, 5(3), 255-266, 1990.

Hildebrandt V. H., Musculoskeletal symptoms and workload in 12 branches of Dutch agriculture. Ergonomics, 38, 2576-2587, 1995.

Jin, S., McCulloch, R. and Mirka, G. A., Biomechanical evaluation of postures assumed when harvesting from bush crops, International Journal of Industrial Ergonomics, 39, 347-352, 2009.

Jung, I. J. and Jung, H. S., Verification of suitable height of plank seat for improving the health and safety of farmers, Journal of the Korean Safety Management and Science, 9(4), 11-16, 2007.

Jung, H. S. and Jung, Hyung-Shik, Evaluation of proper height for squatting stool, Ergonomics, 51(5), 671-690, 2008.

Jung, H. S. and Jung, Hyung-Shik, Evaluation of proper height for squatting stool and the ergonomic design of wearable stool, IE Interfaces, 18(3), 288-296, 2005.

Keyserling, W. M., Brouwer, M. and Silverstein, B. A., A checklist for evaluating ergonomic risk factors resulting from awkward postures of the legs, trunk and neck, International Journal of Industrial Ergonomics, 9, 283-301, 1992.

Kim, K. R., et al. Health condition and musculoskeletal disorders(MSDS) in Fruit-growers, Korean Journal of Community Living Science, 20(1), 5-17, 2009.

Korean Rural Development Administration, Types and characteristics of Agricultural accident through the analysis of farmers' safety compensation data, 2007.

Korean Rural Development Administration, Current status and accident statistics of farmers syndrome, 2006.

Korean Rural Development Administration, '06 '08 The statistics of farmers syndrome, http://www.rda.go.kr/, 2011.

Lee, K. S., et al. A study of agricultural safety technology for ergonomic intervention in farm-work, Journal of the Ergonomics Society of Korea, 29(2), 225-239, 2010.

Lee, K. S., et al. The status of agricultural diseases, injuries and accidents among the England, the USA, the France, the Japan, and the Korea, Korean Journal of Community Living Science, 18(1), 189-204, 2007.

Li, G. and Buckle, P., Current techniques for assessing physical exposure to work-related musculoskeletal risks, with emphasis on posture-based methods, Ergonomics, 42(5), 674-695, 1999.

Meyers, J. M., Injuries among Farm Workers in the United States, 1995. National Institute for Occupational Safety and Health, Report No. 2001-153, 1-295, 2001.

Meyers, J. M., Bloomberg, L., Faucett, J., Janowitz, I. and Miles, J. A., Using ergonomics in the prevention of musculoskeletal cumulative trauma injuries in agriculture: Learning from the mistakes of others. Journal of Agromedicine, 2(3), 11-24, 1995.

Meyers, J. M., Miles, J. A., Faucett, J., Janowitz, I., Tejeda, D. G. and Kabashima, J. N., Ergonomics in agriculture: workplace priority setting in the nursery industry. American Industrial Hygiene Association Journal, 58 (2), 121-126, 1997.

Meyers, J. M., Miles, J., Faucett, J., Janowitz, I., Tejeda, D., Weber, E., Smith, R. and Garcia, L., Ergonomics risk factors for musculoskeletal disorder in wine grape vineyard work. Paper presented at the National Institute for Farm Safety, Winnepeg, Canada, 1998.

Meyers, J. M., Miles, J. A., Faucett, J., Janowitz, I., Tejeda, D. G., Duraj, V., Kabashima, J., Smith, R. and Weber, E., High risk tasks for musculoskeletal disorders in agricultural field work. Paper presented in the IEA 2000/HFES 2000 Congress, 2000.

Ministry of Labor, Industrial Accident Statistics, 2009.

Nemeth, G., Arborelius, U. P., Svensson, O. K. and Nisell, R., The load on the low back and hips and muscular activity during machine milking, International Journal of Industrial Ergonomics, 5(2), 115-123, 1990.

National Institute for Occupational Safety and Health(NIOSH), Work Practice Guide for Manual Lifting, Publication No. 81-122, 1981.

National Institute for Occupational Safety and Health(NIOSH), Musculoskeletal Disorders and Workplace Factors: A Critical Review of Epidemiological Evidence for Work-related Musculoskeletal Disorders of the Neck, Upper Extremity, and Lower Back, DHHS(NIOSH) Publication No. 97-141, 1997.

$\mathrm{Oh}, \mathrm{H}$. O., et al. Prevalence of musculoskeletal symptom in rural farmers, The Journal of Rhumatology Health, 8(1), 86-108, 2001.

Pinzke, S., A computerized system for analyzing working postures in agriculture, International Journal of Industrial Ergonomics, 13(4), 307-315, 1994.

Putz-Anderson, V., Cumulative Trauma Disorders: A Manual for Musculoskeletal Diseases of the Upper Limbs, Taylor \& Francis, London, 1988.

Rural Research Development Institute, A Study of major disease and health behavior of farmers and fishermen, 2004.

Sanders, M. S. and McCormick, E. J., Human Factors in Engineering and Design, Seventh Edition, New York, McGraw-Hill, Inc., 1992.

Walker-Bone, K. and Palmer, K. T., Musculoskeletal disorders in farmers and farm workers, Occupational Medicine, 52(8), 441-450, 2002.

Xing, H. Y., Stallones, L. and Keefe, T. J., Back pain and agricultural work among farmaers: an analysis of the Colorado farm family health and hazard surveillance survey, American Journal of Industrial Medicine, 35, 310-316, 1999 


\section{Author listings}

Hwa Shik Jung: hsjung@dsu.ac.kr

Highest degree: $\mathrm{PhD}$, Department of Industrial Engineering, University of Houston

Position title: Professor, Department of Occupational Therapy, Dongshin University

Areas of interest: Human Factors in Agriculture, MMH, MSDs, OT
Date Received : 2011-06-15

Date Revised :2011-07-26

Date Accepted : 2011-07-26 